\title{
Opuntia ficus-indica the key plant in climate change: characteristics, cultivation and uses
}

\author{
Domenico Prisa * \\ CREA Research Centre for Vegetable and Ornamental Crops, Council for Agricultural Research and Economics, Via dei \\ Fiori 8, 51012 Pescia, PT, Italy.
}

GSC Biological and Pharmaceutical Sciences, 2021, 17(02), 094-105

Publication history: Received on 10 October 2021; revised on 14 November 2021; accepted on 16 November 2021

Article DOI: https://doi.org/10.30574/gscbps.2021.17.2.0333

\begin{abstract}
The Opuntia genus, belonging to the Cactaceae family, has about 300 species, of which Opuntia ficus indica, or Prickly Pear, is considered the best known and most significant.

Opuntia ficus indica have been used in Mexico and Latin America since pre-hispanic times as a food and medicinal resource. In recent years, prickly pear cultivation has increased mainly because this plant used for food, medicinal and livestock purposes is able to withstand extreme drought conditions in relatively poor soils. The fruits of the prickly pear are of various colours such as yellow, orange, purple and white, and when ripe their sweet pulp is characterised by a low acidity. It possesses numerous nutritional and therapeutic virtues such as richness in carbohydrates, vitamins, minerals and considerable antioxidant, anti-diabetes, anti-cancer fruit activity. Opuntia also has laxative properties due to its soluble fibres and mucilage. The infusion of the harvested and dried flowers has a depurative effect; it has a mild, gentle diuretic and relaxing action on the renal excretory system. Opuntias are also exploited as an alternative and cheap source of source of food for animals and as an ornamental plant.

Opuntia ficus indica is grown in subtropical, tropical and warm-temperature areas; it is mainly cultivated in Tunisia, Libya and Egypt. The Prickly Pear finds a particularly favourable habitat in Sardinia, Calabria, Apulia and Sicily, where it is also cultivated, as well as in Spain and North Africa, for the exploitation of its edible fruit, with its delicately sweet pulp, rich in minerals, especially calcium and phosphorus, and vitamin C. In this review, the characteristics, cultivation methods, main uses of the plant and fruits, market and adversities of Opuntia ficus indica are described.
\end{abstract}

Keywords: Opuntia; Succulent plants; Medicinal extracts; Climate change; Anti-cancer fruits

\section{Introduction}

The prickly pear (Opuntia ficus-indica) seems to come from America, probably Mexico, where it is an ancient and widespread plant. There are many hypotheses about the origins of this plant; the most credible one claims that the prickly pear was introduced to Europe in the 16th century, after the discovery of America. Thanks to its adaptability it has spread widely in the Mediterranean basin, reaching as far as the 43rd parallel north. The areas of its cultivation in the world are subtropical, tropical and warm-temperature areas; it is mainly cultivated in Tunisia, Libya and Egypt [1]. Numerous factors have contributed to the spread of the prickly pear in Mediterranean areas, including the southern regions of our country:

\footnotetext{
${ }^{*}$ Corresponding author: Domenico Prisa

CREA Research Centre for Vegetable and Ornamental Crops, Council for Agricultural Research and Economics, Via dei Fiori 8, 51012 Pescia, PT, Italy.
}

Copyright (C) 2021 Author(s) retain the copyright of this article. This article is published under the terms of the Creative Commons Attribution Liscense 4.0. 
- the climatic conditions (hot summers and mild winters with temperatures above $0^{\circ} \mathrm{C}$ ) meet the needs of the plant;

- It has proved to be highly adaptable to the soil environment, growing in arid, rocky and steep places; it is also remarkable for its great resistance to aridity, which allows it to live in drought environments, thanks to the particular structure of the plant and its great ability to use modest quantities of water in the soil;

- easy vegetative propagation by rooting the pads or cladodes

In Italy, the prickly pear is mainly found in Sicily and Calabria, but it is also found in some mild-temperature areas of central and southern Italy (Sardinia, Apulia, Basilicata).

Cultivated for a long time as a marginal plant, it has now become an industrial cash crop, especially in Sicily. It is difficult, however, to know the area covered by this plant in our country, since it is scattered over rough terrain that is difficult to reach, but also because there are plantations that are very fragmented in size [2].

The prickly pear has taken on great agrarian and economic importance, since it grows in drought-prone, poor and poor soil: it is no coincidence that it has been called the "providential bread of the arid regions" and "sweet song" for the sound of the wind as it passes through the branches of the plant. A very generous plant, it is used not only for the production of its very sweet fruit, but also for many other purposes: as a windbreak and protective barrier, as fertilizer and fodder in animal husbandry, and for industrial purposes in the production of textiles. From the paddles that represent the aerial part of the plant it is possible to extract alcohol, healing and diuretic substances $[3,4]$.

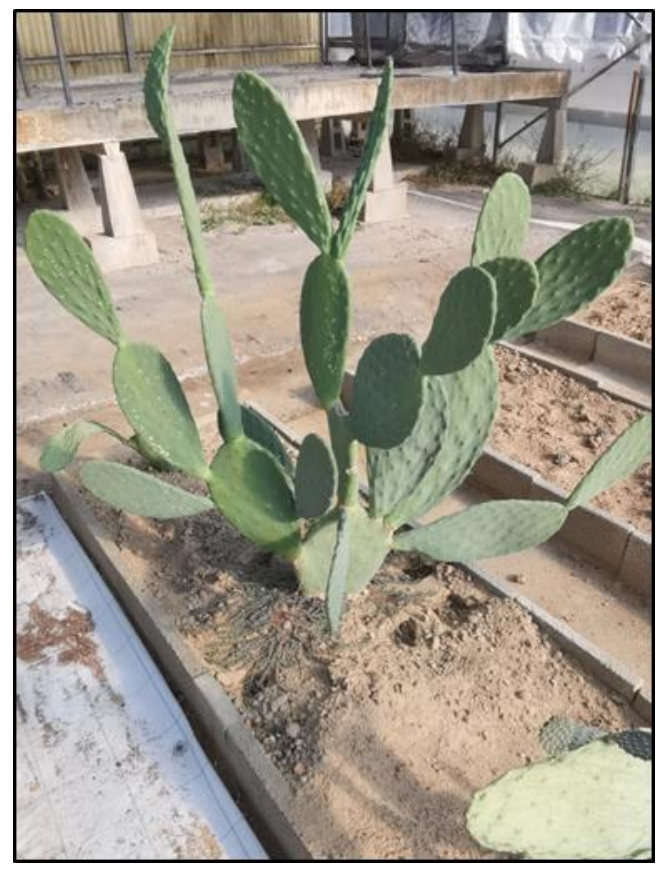

Figure 1 Opuntia ficus indica plant

\subsection{Opuntia ficus-indica environment}

The prickly pear (Opuntia ficus-indica) belongs to the Cactaceae family, which includes a considerable number of plants typical of deserts and arid environments characterized by rare but abundant rainfall. Typical for these plants is the presence of structures in the stem for storing water, which is then gradually used in dry periods [5]. The prickly pear is an arid-resistant species and its expansion is due to the spontaneous nature of this plant and the presence of waterstoring organs, the paddles and cladodes, which enable it to withstand prolonged drought conditions [6].

\section{Botany of the prickly pear}

The prickly pear usually has a bushy appearance, but depending on the soil and climatic conditions, the habit can vary; in favourable environments it can have a tree-like structure. 
The aerial part of the plant is characterized by a system of branches, cladodes or paddles, which not only support and maintain the plant's habit, but also play an important role as water reservoirs. They are in fact fleshy, capable of storing considerable amounts of water that are used during periods of water shortage. For this reason the plant is able to withstand prolonged drought conditions. When this happens, the blades become dehydrated (drooping and dried out), but regain their firmness when the rains come [7]. The blades can also use dew as a water source. On the blades we find the buds that give rise to the leaflets, in correspondence with which spines (thorns), more correctly known as glochids, emerge. The blades vary in size, usually $20-40 \mathrm{~cm}$ long and $15-30 \mathrm{~cm}$ wide, with a thickness of up to $5 \mathrm{~cm}$. The shape is variable, but ellipsoidal prevails. The colour is light green. The blades, being green, carry out chlorophyll photosynthesis instead of leaves. When the blades have lignified they also provide support and scaffolding for the plant, forming the trunk and main branches $[8,9]$.

The trunk is formed by the ageing of the primary, or first-forming blades, which initially take on a dark colour, then a woody texture. If cut above ground level, the trunk behaves like all trees, i.e. it releases suckers and shoots to rebuild the plant [10].

The prickly pear emits woody shoots from the trunk and the main branches which are called suckers and suckers respectively. These branches are particularly important when removing parts of old or frost-damaged plants. They are curved, dark green in colour and therefore easy to recognise; the spiny forms are also very obvious and whitish in colour. The rainy season favours the abundant emission of suckers and shoots [11].

The buds are of two types: flowering and vegetative, i.e. they can give rise to fruit or new blades or cladodes respectively. Their differentiation occurs just before vegetative awakening. In order to distinguish flower buds from vegetative buds it is necessary for the buds to have reached a few millimetres in length: flower buds are spherical in shape, whereas vegetative buds are flattened [12].

The root system is expanded, but shallow. The root mass is located within the first $50 \mathrm{~cm}$ depth of the soil, so the plants do not require deep soil. The capillary roots develop within the first $20 \mathrm{~cm} \mathrm{depth}$. The leaves are observed on the young blades and have a pointed, small shape; they are comparable to small cones ending in a small spine. The leaves, which are scattered over the entire surface of the blades, turn yellow and fall off within 4-5 weeks, leaving the buds surrounded by thorns (glochids) where they were attached.

The flowers are hermaphroditic, i.e. they have both female organs (pistils) and male organs (stamens); they have a dialisepalous calyx (with separate sepals) and a yellow dialipetalous corolla (with separate petals); the ovary is inferior. The colour of the flowers, depending on the variety, can be yellow, green, yellow-orange and red $[13,14]$.

Flowering period begins in May and lasts until the first ten days of June. Each individual flower can remain open for 1015 days, while the fertilization period is limited to a couple of days. Pollination is for the most part autogamous (pollen fertilizes the pistil of the same flower); however, the presence of pollinating insects, especially bees, favours heterogamy (i.e. fertilization by pollen from another plant) and ensures that almost $100 \%$ of the flowers are fruit-bearing (transition from flower to fruit); any few unfertilized flowers persist on the plant for a long time before dropping off [15,16].

The fruit is a berry whose mucilaginous, velvety pulp contains numerous, very hard, dark-coloured seeds. In fact, the seeds have a coating that is very resistant even to the action of gastric juices, so that they are expelled by animals in their entire state; in practice, their germination capacity remains intact, which explains why prickly pear plants grow in inaccessible areas, where birds with a taste for the fruit have probably settled. The skin (epicarp) consists of a tough tissue about $4 \mathrm{~mm}$ thick of variable colour. When the fruit is ripe the skin varies from green to yellow-orange to red [17]. On the inside the tissue is velvety, while on the outside the surface is dotted with dark-brown eyes with spines. The colour of the flesh varies according to the variety, from yellow or orange (sulphur variety), to blood red (red variety) and straw-white (muscaredda variety). The fruits can be stalked or sessile (i.e. without stalk). The stalked ones show an extension of the epicarp formed, by mutation, through the practice of vegetative or agamic multiplication. The peduncle is several centimetres longer than the sessile fruit [18].

The normal biological cycle of the prickly pear is characterized by the production and harvesting of the fruit in AugustSeptember. However, the quality characteristics of the summer fruits are not good: they are small in size, have less succulent flesh and contain more seeds. The scozzolatura operation, which consists of manually removing the first flowers, stimulates a new, later flowering; scozzolatura makes it possible to harvest the so-called bastardoni fruits from October to December. The 'bastardoni' are definitely of higher quality: the size is larger, the flesh is more succulent and there are fewer seeds. The percentage of seeds in the fruit varies depending on whether it is Augustan (10\%) or bastardoni (5\%). The seeds contain a high nutritional value; if they are ground, they are an excellent food for livestock 
on a par with the flour obtained from the best forage crops. In the best soils, prickly pears are tastier and sweeter and the plants are more luxuriant. Longevity also improves the quality of the fruit, with some plants remaining in production for at least 35-40 years $[1,19,20]$.
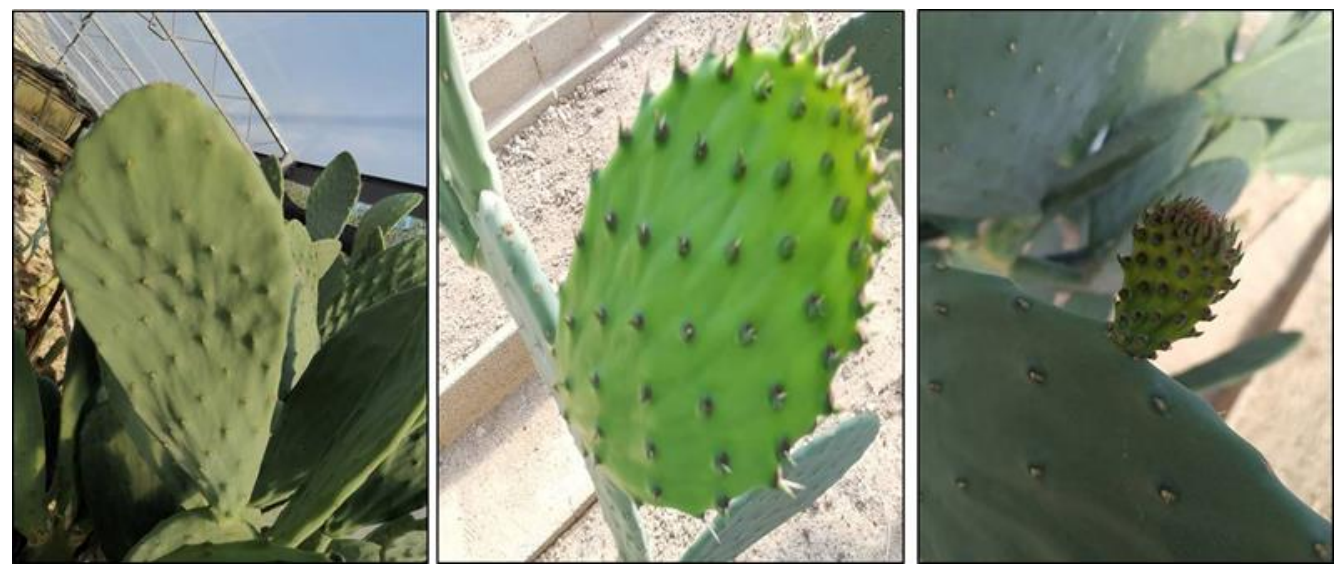

Figure 2 Opuntia ficus indica cladodes

\section{Cultivation soil and climate}

Looking at where the prickly pear tree grows, one can see that the plant has a remarkable level of soil adaptability; it is able to grow in dry, poor, rocky and steep soils. Volcanic, loose, medium-textured soils are ideal; soils subject to water stagnation and very loamy and silty soils are unsuitable, as the plant may develop Phythophtora cactorum rot and thus have a slow growth rate.

The plant withstands climatic conditions typical of arid tropical countries; the prickly pear bears high temperatures (over $40^{\circ} \mathrm{C}$ ), remaining physiologically active, in fact the fruits ripen during the hottest periods of the year. Its resistance to drought is due to its blades, which act as real water reservoirs; during dry periods the plant lives at the expense of reserve water [21].

The optimal temperatures at which this cactus grows well are between $10-15^{\circ} \mathrm{C}$ in winter and $30-35^{\circ} \mathrm{C}$ in summer; temperatures of $3-4^{\circ} \mathrm{C}$ below zero are to be considered as the minimum limits within which the blades do not brown and die of the tissues. As far as altitude limits are concerned, the plants can grow up to $1000 \mathrm{~m}$ above sea level [1,22].

\section{Prickly pear varieties}

There are three varieties of prickly pear which have assumed particular economic importance and lend themselves to specialized cultivation $[1,23,24]$ :

- the yellow variety, called sulfarina;

- the red variety, known as sanguine;

- the white variety, known as muscaredda;

The main objectives of the research are:

- greater suitability of the fruit for cold storage;

- greater plant resistance to low temperatures;

- obtaining fruit with a thornless skin;

- obtaining seedless fruit.

Table 1 Comparison of size, weight and fruit parts of different prickly pear varieties [1] 


\begin{tabular}{|l|c|c|c|c|c|c|c|c|c|}
\hline \multirow{2}{*}{ Varieties } & \multicolumn{3}{|c|}{ Area } & \multicolumn{3}{c|}{ First-harvest fruit } & \multicolumn{3}{c|}{ Summer fruits } \\
\cline { 2 - 10 } & $\begin{array}{c}\text { Trasversal } \\
\text { (cm) }\end{array}$ & $\begin{array}{c}\text { Longitudinal } \\
\text { (cm) }\end{array}$ & $\begin{array}{c}\text { Weight } \\
\text { (g) }\end{array}$ & $\begin{array}{c}\text { Peel } \\
\text { (g) }\end{array}$ & $\begin{array}{c}\text { Pulp } \\
\text { (g) }\end{array}$ & $\begin{array}{c}\text { Seeds } \\
\text { (g) }\end{array}$ & $\begin{array}{c}\text { Peel } \\
\text { (g) }\end{array}$ & $\begin{array}{c}\text { Pulp } \\
\text { (g) }\end{array}$ & $\begin{array}{c}\text { Seeds } \\
\text { (g) }\end{array}$ \\
\hline Yellow (Sulfarina) & 5.0 & 9.0 & 130.0 & 50.0 & 76.0 & 4.0 & 24.0 & 50.4 & 5.6 \\
\hline Red (Sanguine) & 5.0 & 12.0 & 135.0 & 60.0 & 71.0 & 4.0 & 24.0 & 50.4 & 5.6 \\
\hline $\begin{array}{l}\text { White } \\
\text { (Muscaredda) }\end{array}$ & 4.5 & 8.5 & 125.0 & 55.0 & 65.0 & 5.0 & 24.0 & 50.4 & 5.6 \\
\hline
\end{tabular}

\section{Growing technique}

Prickly pear cactus does not like stagnant soils or grows poorly in them; clayey or loamy soils should therefore be avoided, while values around neutral $(6,8-7,2)$ are the best for the crop as far as $\mathrm{pH}$ is concerned. Prickly pear production can be started from seed, plant parts, blades or cladodes.

The seeds are collected from ripe fruit, which is peeled and placed in a blender and diluted in water several times. Once the pulp-water-seed mixture is obtained, the seeds are separated through filtration [25]. Close-meshed gauze filters are used. The seeds obtained are then dried in an airy place for 1 day. The seeds obtained can also be stored well in normal plastic containers for a period of a few years. The best time to sow prickly pear is April. A commercial soil of sand and peat is normally used. Then sow the seeds in rows $10 \mathrm{~cm}$ apart or in plastic pots. It is advisable to sow more seeds as the germination rate of prickly pear is around $30-50 \%$ [26].

The minimum and maximum temperature values for germination are $14-16^{\circ} \mathrm{C}$ and $28-30^{\circ} \mathrm{C}$ respectively. Within $4-5$ weeks the formation of the small blades takes place. Post-seeding care can be summarised as follows: weed removal, moderate water supply, control of phytopathogens. Sowing 500 seeds in one square metre of land can produce around 90 plants.

Vegetative propagation by plant parts (agamic) produces plants identical to the one from which they are derived. The plant parts used for vegetative propagation are the blades and cladodes. A part of a blade may be sufficient to obtain a new plant, but it is advisable to use whole blades or cladodes. The mother plants should be taken in May, when wounds are easily healed. The shovels should be 1-2 years old [27].

A basic organic fertilization of $100 \mathrm{t} / \mathrm{ha}$ of well matured manure is recommended to be buried at a depth of $20-30 \mathrm{~cm}$. Together with the organic substance, phosphate and potassium mineral fertilizers can be used, bearing in mind the data from the chemical analysis of the soil and the needs of the plant. The indicative doses are: $0.7 \mathrm{t} / \mathrm{ha}$ of mineral superphosphate and $0.3 \mathrm{t} / \mathrm{ha}$ of potassium sulphate. The most suitable planting pattern for prickly pear cultivation is 6 $7 \mathrm{~m}$ between rows and 4-5 $\mathrm{m}$ on the row, if used as a windbreak the plants should be spaced $3 \mathrm{~m}$ apart [28].

The position of the blade must be such that the cross-section is normal to the longitudinal direction of the planting row. The preferred orientation of the row is north-south, so that the plants can benefit from more sunlight. the blade should be approximately half buried. If no adverse factors are involved, the rooting rate of the shovels is almost always total. After fertilising with manure at the time of planting, from the fifth year onwards $75 \mathrm{~kg}$ of ammonium sulphate, $7.5 \mathrm{~kg}$ of superphosphate and $30 \mathrm{~kg}$ of potassium sulphate should be added. Fertilisation should be carried out two to three times (spring, August and autumn), burying the fertilisers below the surface $(5-10 \mathrm{~cm})[1,29]$.

\section{Cultivation form and pruning methods}

The current guidelines for prickly pear breeding are for the free form. This involves letting the plant grow according to its natural tendency. Pruning should facilitate this formation. Pruning in the prickly pear is defined as the removal of entire blades.

In the case of breeding pruning, blades that are supernumerary or in an abnormal position are removed in spring, in May to be precise, and any parts that have deteriorated and folded in on themselves are also removed. As a rule, at least two blades should be left per prickly pear plant in order to obtain a $V$ formation $[1,30]$. 
In the production pruning, the damaged, old, poorly positioned and poorly fruiting prickly pear blades are removed, favouring the development of young blades (the highest fructification occurs on one-year-old blades grown on 2-3-yearold blades). All suckers and suckers developing in the lower part of the plant should also be cut. Production pruning is carried out in April-May, before the plants regrow [31].

Renewal pruning is carried out when the plants are old and produce little, usually after 40-50 years. It is carried out in April by cutting the plant at $50-60 \mathrm{~cm}$ from the ground; the pruning will stimulate the formation of suckers that will be used to reform the plant in a few years.

In the scozzolatura the first flowers are removed in order to stimulate a new flowering, later, with the aim of delaying the harvest of the fruits. It is carried out in May-June and the fruits obtained from scotched plants are harvested in October-December. Scozzolatura causes fewer flowers to be produced than at the time of the first flowering; in practice, scozzolatura must be considered a technique of forcing the plant. When there is continuous rainfall in the spring, part of the countless new blades that have formed as a result of the particular rainfall conditions are removed; the large number of blades would have a negative effect on the production and quality of the bastards.

The aim of thinning is to reduce the number of fruits on the blades in order to allow, as with thinning, higher quality production. As a rule, no more than 5 fruits per blade are left well spaced, the others being removed. Fruit thinning is carried out after the berries have set, in July [32].

\subsection{Irrigation}

Abundant irrigation (8000-10000 l, per $1000 \mathrm{~m}^{2}$ ) is necessary after scotching, unless there has been heavy spring rainfall. A further 2-3 irrigations if necessary are best carried out in August-September with the same amount of water. Watering should be done under the foliage with drip irrigation or spraying. The purpose of under-canopy irrigation is not to encourage the spread of diseases.

\section{Harvesting, marketing and main uses}

In a specialised cultivation, production can reach and exceed $30 \mathrm{t} / \mathrm{ha}$, but there is a tendency to reduce the number of fruits per plant to be brought to maturity by thinning, in order to improve quality values; therefore, sometimes the production per hectare is around 15-20 t. On small family holdings, individual trees produce an average of $40 \mathrm{~kg}$ of fruit after the fifth year. Young trees up to three years old can produce up to $10 \mathrm{~kg}$ of fruit.

\subsection{Harvesting}

To assess the ripeness of the fruit, the colour of the skin can be observed, which must be typical of the variety, or samples can be taken from different plants. The fruit is picked by hand, using a sharp knife. The cut must be clean and also involve a blade appendage $(1 \mathrm{~cm})$ to avoid rotting in the fruit. When harvesting, it is essential to protect the hands from the thorns with strong, thick rubber gloves. Harvesting is best done in the morning when the thorns are less rigid due to the moisture [33].

\subsection{Marketing}

Marketing involves a series of operations before the fruit is placed on the market; in order they are: selection, packaging, storage.

\subsubsection{Selection}

This operation consists of cataloguing the fruit according to variety and size. Selection is essential if the fruit is to be packaged in a homogeneous manner. Most of the sorting is carried out in special premises, according to criteria derived from market demands. The fruit is divided mainly into two classes (I and II), while the others that do not fall into the two classes are discarded fruit. In both classes the fruit must have certain basic characteristics. They must be:

- $\quad$ whole, firm, healthy: fruit affected by alterations that make it unfit for consumption is excluded;

- clean, practically free of any visible foreign matter, free of any particular taste or smell.

The fruit must also withstand transport and the associated operations in order to arrive at the place of destination in a condition suitable for sale and consumption. First class fruit is usually packed in single-layer plastic crates and second class fruit in multi-layer wooden crates [34]. 
Particularly interesting is the use of grading machines, similar to those used for sorting other fruit; their use is certainly indicated for cooperatives and not for the individual producer with limited production capacity. It is a good idea to market fruit without thorns; this can be achieved with the help of special despinner machines which remove thorns and other foreign bodies, thus making the fruit manageable. The removal of the thorns from the fruit is important not only to enable the fruit to be handled, but also because the thorns can penetrate the skin and facilitate the entry of pathogens. Mechanically de-thorned fruit is the same as fruit that does not receive this treatment as far as cold storage and resistance to transport are concerned. The despinatrice removes only the thorns, leaving the halos on the epicarp intact [35].

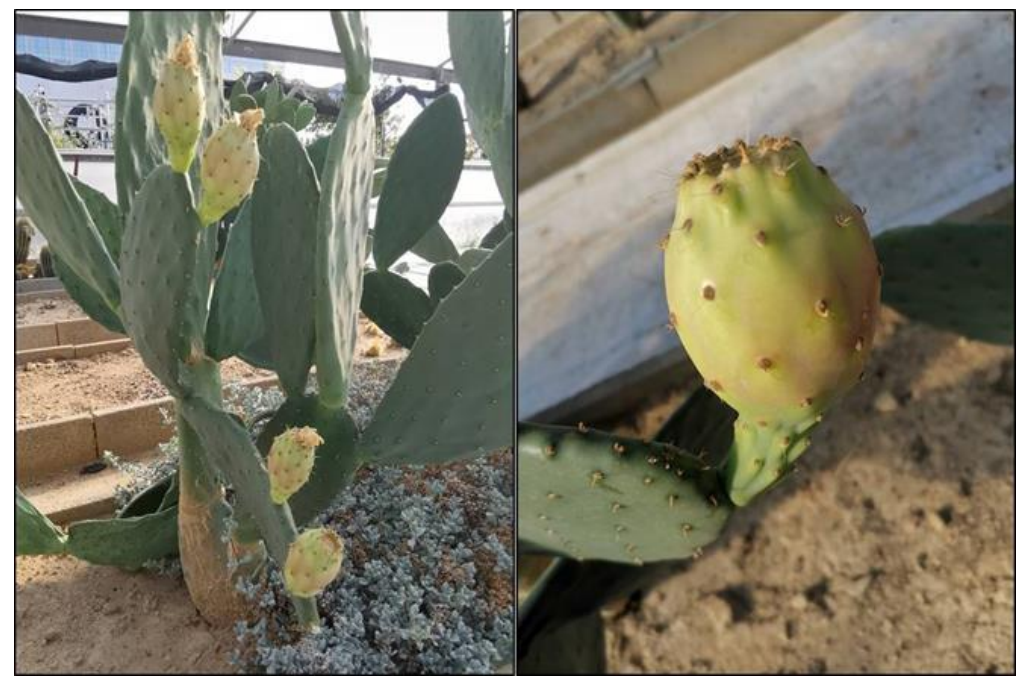

Figure 3 Opuntia ficus indica fruits

\subsubsection{Packaging and storage of fruit}

Marketing requires obtaining a standard product, i.e. one of consistent quality, carefully packed and stored. The most common packaging consists of wooden crates containing about $20 \mathrm{~kg}$ of product. Before sale, the product can be stored in a cool, ventilated place for a maximum of 60-70 days, and the fruit can be kept in the fridge at a temperature of $3^{\circ} \mathrm{C}$. Anything below this level risks browning and softening of the fruit, a phenomenon known as 'allessatura'.

Refrigeration allows the fruit to keep for several months. In addition to the temperature in the refrigerated rooms, it is important to ensure adequate air circulation, an adequate relative humidity level (90\%) and control of ethylene, which is a gas that originates during the ripening process and promotes ripening of the fruit. In the cold rooms there are always special filters to purify the air of ethylene gas. Prickly pears should not be stored in refrigerated rooms where other species of fruit that also produce ethylene (apples, pears, bananas) are stored. Storage in a non-refrigerated environment should take into account ventilation and light, which should not be direct. Therefore, family storage of prickly pear fruit should take place in rooms with diffuse light, which are cool but not excessively humid and which allow easy air exchange. The fruit should be placed on a perforated shelf so as to ensure ventilation in all parts, in an upright position, with the stalk upwards and one next to the other [36].

\subsubsection{Prickly pear market and uses}

The prickly pear market covers our country and abroad (Canada, United States). The bastard fruits of the yellow and red varieties must be considered of international quality. Since quality is a very important factor in winning over the market, a great deal of emphasis must be placed on this factor, but at the same time incisive marketing action is needed to increase consumption. The main markets in Italy for the sale of prickly pears are Apulia, Rome, Fondi, Turin and Milan.

All the organs of the prickly pear can be used for different purposes. the destination of the fruit in its fresh state for human consumption is in fact not the only use.

In Sicily, the use of prickly pear flowers has been passed down for the beneficial and therapeutic activities they produce. In particular, the infusion of the picked and dried flowers has a purifying effect; it has a mild and gentle diuretic and relaxing action on the renal excretory system, it facilitates renal filtration and in particular it is consecrated by popular 
use for its action on uro-micro-lithiasis ("renella") as it facilitates the elimination and expulsion of kidney stones. The fruit repeats the action of the flowers because it facilitates renal function as a whole. The fruit, if consumed in large quantities, gives the urine a reddish colour reminiscent of the fruit flesh. The effect on kidney function is gentle and in accordance with nature, to which is added a coordinating and rebalancing action on the functional cooperation between kidney and liver, so the prickly pear is always recommended to subjects who have an overload of metabolic, renal and hepatic work [37].

Although prickly pears are grown mainly for fruit production, their use in livestock feed should not be overlooked. The prickly pears are cultivated as a fodder plant to be harvested and fed at the feeding trough. These should be cut with a sharp knife, wearing gloves, at the point of insertion of the blade underneath. Within a short time the plants generate new blades which can be used in the following year. It is a good idea to cut the shovels into slices before placing them in the trough to facilitate ingestion by the animals. It should be borne in mind that animals feeding on this food rarely need to drink because the paddles are rich in water. Prolonged feeding on shovels alone can, however, lead to deficiencies which should be prevented by supplementing with concentrated feed, hay and sometimes straw. The fruit can also be used for the extraction of ethyl alcohol (ethanol); for this purpose, the Augustan fruit is very suitable because production costs are lower, since it is not squashed. There are no irrigation systems for Augustan fruit and production is higher in quantity. The fruit sent to the distillery is first stripped of its seeds, which in turn contain about $10 \%$ oil. A total of $1000 \mathrm{~kg}$ of alcohol and $37 \mathrm{~kg}$ of oil can be extracted from 10 tons of fruit [38,39].

Table 2 Energy value and content of prickly pear fruit per $100 \mathrm{~g}$ of pulp

\begin{tabular}{|l|c|l|c|}
\hline Energy value and contents & Value & Energy value and contents & Value \\
\hline Calories (Kcal) & 40.00 & Fibers (g) & 3.6 \\
\hline Water (\%) & 83.20 & Cholesterol (mg) & 0 \\
\hline Protein (g) & 0.80 & Mg (mg) & 85 \\
\hline Lipid (g) & 0.10 & Zn (mg) & 0.12 \\
\hline Sugars (g) & 12.30 & Cu (mg) & 0.008 \\
\hline Vitamin B (mg) & 0.01 & Se (mg) & 0.6 \\
\hline Vitamin B (mg) & 0.03 & Vitamin B3 (mg) & 0.5 \\
\hline Vitamin C (mg) & 17.00 & Vitamin E (mg) & 0.01 \\
\hline Vitamin A (mg) & 10.00 & Na (mg) & 5 \\
\hline Ca (mg) & 56.00 & P (mg) & 24 \\
\hline Fe (mg) & 0.40 & K (mg) & 220 \\
\hline
\end{tabular}
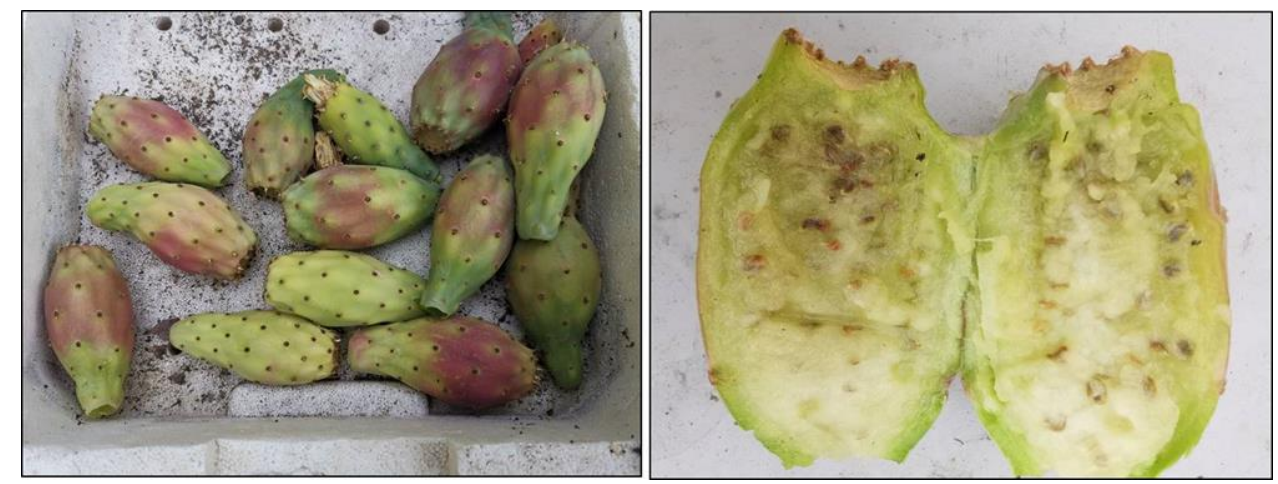

Figure 5 Opuntia ficus indica fruits harvest and detail of the inside of the fruit 


\section{Adverse events}

The main prickly pear pests can be caused by fungal pests (cryptogams), animal pests (phytophagous pests) and some non-parasitic phenomena (meteoric pests) $[1,40,41]$.

\subsection{Fungal pests}

The damage caused by the deuteromycete fungus Phillosticta opuntiae is on the blades or cladodes, especially on young blades up to 2 years old. The cladodes show rusty-yellow spots; at first the spots are small, but as the disease progresses they become larger and affect large areas of the affected organs. Over time, the tissues of the affected blades take on a scabby appearance, i.e. the parts attacked by the fungus dry out and detach themselves from the healthy parts or rot. The development of the pathogen is favoured by high temperature and relative humidity in late spring and autumn. The affected plants have a generally distressed appearance; if the disease is at an advanced stage they are incurable.

The only possible control is prevention, which is carried out by spraying with Bordeaux mixture or other specific products (in spring and autumn). The 1\% Bordeaux mixture limits the harmful action of the pathogen. It is also advisable to remove and destroy all infected parts.

The pathogens responsible for prickly pear rot are the ficomycete fungi Phytophtora cactorum and Phytophtora omnivera. The affected plants are in a debilitated state, and the cladodes and fruits have a chlorotic appearance and suffer a vegetative blockage over time: the fruits do not progress, so they do not reach maturity; the tissues of the affected organs (collar and roots) appear brownish and are very fragile. Due to the pathogenic action of the fungus mentioned, secretions are emitted from the affected areas with an unpleasant smell.

The disease is favoured by excess atmospheric and soil moisture, and prickly pear cultivations on clay and loamy soils are particularly susceptible.

It is therefore essential to carefully assess the soil conditions before allocating land for prickly pear cultivation. Rot is the most serious prickly pear disease. Irreparably affected plants, on the other hand, must be removed along with their roots and destroyed to prevent further spread of the fungus.

\subsection{Animal pests}

\subsubsection{Fruit fly}

This is the Ceratitits capitata insect, belonging to the Diptera order, which attacks a myriad of fruits of different species, causing considerable damage to production. The fruit fly is widespread in all tropical and subtropical areas of the world. Depending on climatic conditions, it can give rise to 3 to 6 generations in a year. Affected fruits are easily identifiable because they show dark spots at the site of oviposition. A sugary liquid escapes from the same hole caused by the ovipositor, attracting ants and other insects. The parasitised fruits fall early and are therefore not suitable for direct consumption or marketing.

\subsubsection{Cochineal}

In the presence of localised and accessible attacks, an attempt can be made to remove the parasites manually with cotton wool soaked in alcohol; the material is then destroyed. In the case of widespread attacks, specific products should be used.

\subsubsection{Snails and slugs}

Slugs and snails are responsible for considerable damage to prickly pear plants. These molluscs are greedy for the cladodes, which they eat at night, while they remain hidden during the day.

\section{Adverse weather conditions}

\subsection{Cold damage}

The prickly pear, like all cacti, is characterised by a fleshy structure, i.e. made up of water-rich organs, so that low temperatures can cause loosening damage to the cladodes; the plants can withstand temperatures as low as $-3^{\circ} \mathrm{C}$ during the winter season. Below this temperature the damage is gradual until the aerial part is completely burnt. At a 
temperature of $-10^{\circ} \mathrm{C}$ the prickly pear suffers complete destruction of the aerial part, but the plant can reform. Dangerous autumn frosts can cause damage to the blades and fruit.

Wounds damaged by frost and hoarfrost should be removed at a time when the sun helps the wounds to heal, in order to avoid rotting, i.e. when pruning in April-May. Against frost damage, frost-free irrigation systems can prevent or reduce damage.

\subsection{Heat damage}

The prickly pear, thanks to its particular morphological structure, is able to overcome long periods of excessive heat and prolonged drought simply by reducing its physiological activities: in practice the plant is like going into dormancy. As far as water use is concerned, it makes use of the water reserves contained in the cladodes.

\subsection{Humidity}

This is harmful if it exceeds certain limits both in the soil and in the atmosphere. Waterlogging in the soil and heavy rainfall encourage the spread of fungal diseases such as Phytophtora spp. rot.

\subsection{Hail}

It is responsible for considerable damage because it causes numerous wounds to the cladodes; the wounds are often the entry point for many pathogens, particularly on the fruit which, given the delicacy of the skin tissues (epicarp), are irreparably damaged. The damage is commensurate with the time of the event: if the hailstorm occurs in spring, the plants have the opportunity to generate new shoots; autumn hailstorms, on the other hand, are the most damaging as they affect both the fruit and the cladodes responsible for the following year's production.

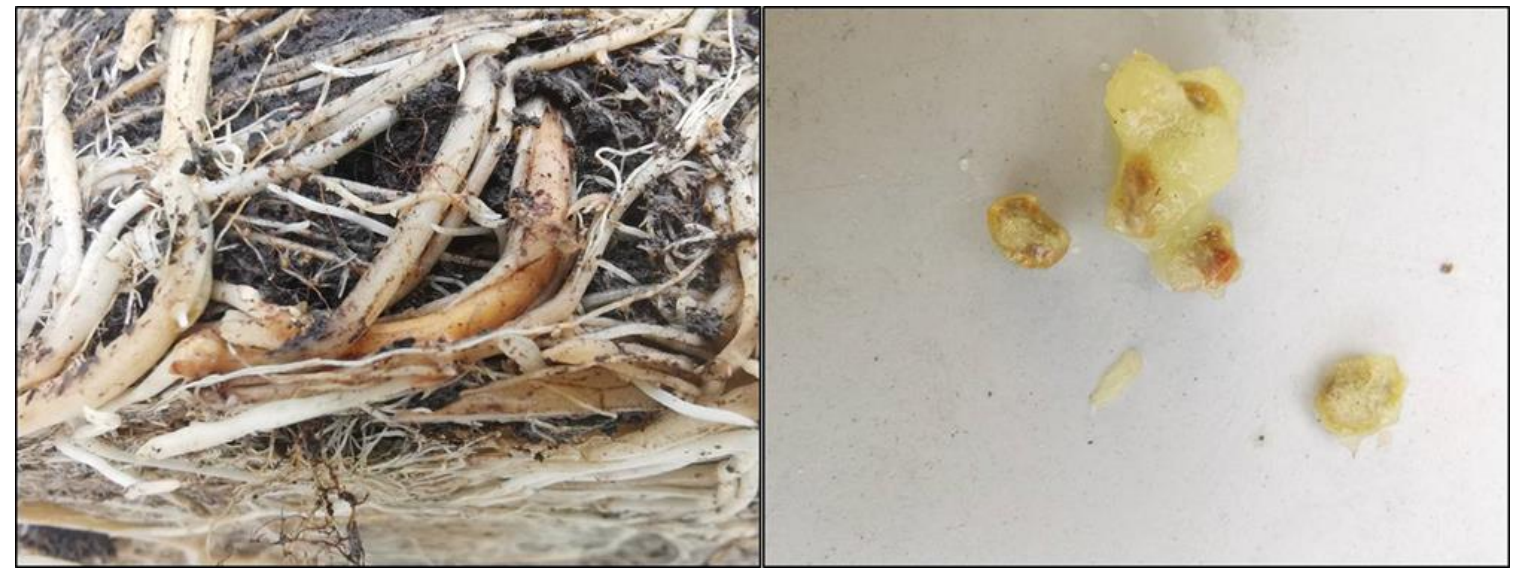

Figure 6 Roots system and mucilage-wrapped seeds of Opuntia ficus indica

\section{Conclusion}

The Opuntia ficus-indica (or prickly pear), is one of the main species of the genus Opuntia, plants belonging to the Cactaceae family, native to the Americas, where they are widespread in arid tropical and subtropical areas. The prickly pear now grows wild throughout the Mediterranean basin, including Italy, and is the only naturalised opuntia in Europe. Opuntias have a rare feature in the plant kingdom: not only do they have edible flowers and fruit, but part of their stems can also be eaten. The qualitative and medicinal characteristics of the fruit, its use in animal husbandry and for the production of textiles and dyes, together with its resistance to drought, make Opuntia ficus indica one of the plants of the future that can certainly be used by man following climate change.

\section{Compliance with ethical standards}

\section{Acknowledgments}

The research is part of the project "MicroSuc: microorganisms for the growth and protection of cacti and succulent plants". 


\section{Disclosure of conflict of interest}

The author declares no conflict of interest.

\section{Statement of ethical approval}

The present research work does not contain any studies performed on animals/humans subjects.

\section{References}

[1] Cacioppo O. Fico d'India e Pitaya. I libri di vita in campagna, L'informatore agrario. 1991.

[2] Reynolds SG, Arias-Jimenez E, Mondrago C, Perezgonzales S. El nopal (Opuntia spp.) como forraje.Estudio FAO Produccion y Proteccion Vegetal. 2003; 169: 344-345.

[3] Piga A. Cactus pear: A fruit of Neutraceutical and Functional Importance. J.PACD. 2004; 9-22.

[4] Stintzing FC, Carle R. Cactus stems (Opuntia spp.): A review on their chemistry, technology, anduses. Mol. Nutr. Food Res. 2005; 49: 175-194.

[5] Jiménez-Aguilar DM, Mújica-Paz H, Welti-Chanes J. Phytochemical Characterization of Prickly Pear (Opuntia spp.) and of its Nutritional and Functional Properties: A Review. Current Nutrition \& Food Science. 2014 ; 10 : 57 69.

[6] Saenz C. processing technologies: an alternative for cactus pear (Opuntia spp.) fruits and cladodes. Journal of Arid Environments. 2000; 46: 209-225.

[7] El-Mostafa K, El KharrassiY, Badreddine A, Andreoletti P. Nopal Cactus (Opuntia ficus-indica) as a Source of Bioactive Compounds for Nutrition. Health and Disease review, Molecules. 2014; 19: 14879-14901.

[8] Barbera G, Inglese P, Pimienta-Barrios E. Agro-Ecology Cultivation and Uses of Cactus Pear. FAO Plant Production and Protection Paper No. 132, Food and Agriculture Organization of the United Nations, Rome. 1995.

[9] Butera D, Tesoriere L, Di Gaudio F, Bongiorno A, Allegra M, Pintaudi M, et al. Livrea. Antioxidant activities of Sicilian prickly pear (Opuntia ficus-indica) fruit extract and reducing properties of its betalains:betanin and indicaxanthin. Journal of Agriculture and Food Chemistry. 2002; 50: 6895-6901.

[10] Diaz F, Santos M, Filardo S, Villagómez R, Scheinvar L. Colorant extraction from red prickly pear (Opuntia lasiacantha) for food application. Journal of Agriculture and Food Chemistry. 2006; 5: 1330-1337.

[11] Feugang M, Konarski P, Zou D, Stintzing C, Zou C. Nutritional and medicinal use of Cactus pear (Opuntia spp.) cladodes and fruits. Fruit Bioscience. 2006; 11: 2574-2589.

[12] Inglese P, Basile F, Schirra M. Cactus pear fruit production Cacti: Biology Uses, P. S. Nobel, University of California Press, Berkeley. 2002; 163-183.

[13] Kuti O. Antioxidant activity of Opuntia cactus pear. Journal of Horticulture Science. 2000; 35: $433-438$.

[14] Matsuhiro B, Lillo E, Sáenz C, Urzúa C, O Zárate. Chemical characterization of the mucilage from fruits of Opuntia ficus-indica. Carbohydrate Polymer. 2006; 63: 263-267.

[15] Piga A. Cactus pear: a fruit of nutraceutical and functional importance. Journal of the Professional. Association for Cactus Development. 2004; 9-22.

[16] Yahia EM, Mondragon-Jacobo C. Nutritional components and anti-oxidant capacity of ten cultivars and lines of cactus pear fruit (Opuntia spp.). Food Res. Intern. 2011; 44: 2311-2318.

[17] MS Santos Díaz, AP Barba de la Rosa, C Héliès-Toussaint, F Guéraud, A Nègre-Salvayre, Opuntia spp. characterization and benefits in chronic diseases-review. Oxid. Med. Cell. Longev. 2017.

[18] Griffith MP. The origins of an important cactus crop, Opuntia ficus-indica (cactaceae) new molecular evidence. American Journal of Botany. 2004; 91(11): 1915-1921.

[19] Said-Al Ahl HAH, Astatkie T, Hikal W. Opuntia ficus-indica (cactus pear) multipurpose plant for the future. Book, Noor Publishing; Noor Publishing, Omni Scriptum GmbH \& Co. KG Bahnhofstraße 28, 66111 Saarbrücken, Germany. 2017.

[20] Haile M, Belay T, Zimmermann HG. Current and potential use of cactus in Tigray, Northern Ethiopia. Acta Horticulture. 2002; 581: 75-86. 
[21] DeFelice MS. Prickly pear cactus, Opuntia spp. A spine-tingling tale. Weed Technology. 2004; 18(3): 869-877.

[22] Gurrieri S, Miceli, L, Lanza, CM, Tomaselli F, Bonomo RP, Rizzarelli E. Chemical characterization of Sicilian prickly pear (Opuntia ficus-indica) and perspectives for the storage of its juice. Journal of Agriculture and Food Chemistry. 2000; 48(11): 5424-5431.

[23] Perfumi M, Tacconi R. Effect of Opuntia ficus-indica flower infusion on urinary and electrolyte excretion in rats. Fitoterapia. 1996; 67: 459-464.

[24] Barbera G, Carimi F, Inglese P. The reflowering of prickly pear Opuntia ficus-indica (L.) Mill. influence of removal time and cladode load on yield and fruit ripening. Advances in Horticulture Science. 1991; 2: 77-80.

[25] Barbera G, Inglese P. La coltura del Ficodindia, Edagricole. 1993.

[26] Cantwell M. Post-harvest management of fruits and vegetable stems. In G. Barbera, P. Inglese, and E. PimientaBarrios (Eds.), Agro-ecology, cultivation and uses of cactus pear. Rome: Food and Agriculture Organization of the United Nations. 1995; 120-141.

[27] Chessa I, Barbera G. Indagine sulla frigoconservazione dei frutti della cv 'Gialla' di ficodindia. Frutticoltura. 1984; 46: 57-61.

[28] Damigella P. Contributo alla conoscenza della biologia fiorale e di fruttificazione del fico d'india. Tecnica Agricola. 1957; 5: 353-371.

[29] Almanza P. El higo Opuntia ficus - indica, una alternativa para zonas semiáridas. Agrodesarrollo. 1992; 3(2): 3748.

[30] Cuta E. Estrategias de la producción pecuaria en la cadena productiva de cactus nopal (Opuntia ficus indica) para el municipio de Betéitiva. Trabajo de grado. Tunja, Colombia: Facultad de Ciencias Agropecuarias, uptc. 2005.

[31] Prisa D. Comparison between sterilized zeolite and natural zeolite in the Cactus Pear (Opuntia Ficus-Indica L. Mill.) growing. GSC Advanced Research and Reviews. 2020; 04(03): 007-014.

[32] Le Houérou HN. The role of cacti (Opuntia sp.) in erosion control, land reclamation, rehabilitation and agricultural development in the mediterranean basin. Journal of Arid Enviroments. 1996; 33: 135-159.

[33] Ochoa C, Aristizábal JD. El higo (Opuntia ficus indica (L.) Miller); un cultivo con grandes perspectivas del que hay mucho por conocer. Agricultura Tropical. 1991; 28(2): 65-72.

[34] Aristizábal D, Ochoa C. El cultivo del higo (Opuntia ficus indica L. Miller). Boletín Técnico No. 1. Medellín, Colombia: Facultad de Ciencias Agropecuarias, universidad Nacional de Colombia. 1992; 13-17.

[35] Pimienta BE. Vegetable cactus pear (Opuntia spp.). En: Underutilized crops, pulses and vegetables. Londres: Chapman \& Hall. 1993; 177-191.

[36] Guzmán D, Chávez J. Estudio bromatológico del cladodio del nopal (Opuntia ficus-indica) para el consumo humano. Revista de la Sociedad Química del Perú. 2007; 73(1): 41-45.

[37] Maldonado JL, Zapien B. El nopal en México. Ciencia Forestal en México. 1977; 2(5): 36-53.

[38] Flórez G, Rojas Z. Efectos de sustratos, posición y origen de los esquejes en el enraizamiento de tuna (Opuntia ficus indica L.) en Tunja, Boyacá. Trabajo de grado. Tunja, Colombia: Facultad de Ciencias Agropecuarias, uptc. 1991.

[39] Méndez-Gallegos S, Talavera Magaña D, Javier García Herrera E. Identificación y control de las enfermedades más comunes en el nopal. Revista Salud Pública y Nutrición. 2008; 14: 105-113.

[40] Flores-Hernández A, Trejo R, Arreola JG, Orona-Castillo I, Murillo-Amador B, Rivera M, Martínez JG and García EA.. Seasonal prickly pear production under drip irrigation in an agricultural region of Mexico. Journal of the Professional Association for Cactus Development. 2005; 6: 84-96.

[41] Scheinvar L. Taxonomy of utilized Opuntias, in: Barbera G, Inglese P, Pimienta-Barrios E, (editors), Agroecology, cultivation and uses of cactus pear. FAO Plant Production and Protection Paper, Rome. 1995; 20-27. 